\title{
WSPOMNIENIE O PROFESOR EWIE BOJENKO-IZDEBSKIEJ
}

8 października 2017 r. zmarła Profesor Ewa Bojenko-Izdebska, adiunkt w Katedrze Stosunków Międzynarodowych i Polityki Zagranicznej w Instytucie Nauk Politycznych i Stosunków Międzynarodowych Uniwersytetu Jagiellońskiego, uznana badaczka problematyki niemcoznawczej, autorka licznych publikacji naukowych, tłumaczka przysięgła języka niemieckiego.

Ewa Bojenko-Izdebska urodziła się 25 maja 1951 r. w Krakowie. Ukończyła V Liceum Ogólnokształcące im. Augusta Witkowskiego w Krakowie, a następnie podjęła studia na Uniwersytecie Jagiellońskim na kierunku filologia germańska. Zgodnie z obowiązującym w Polskiej Rzeczpospolitej Ludowej nakazem pracy

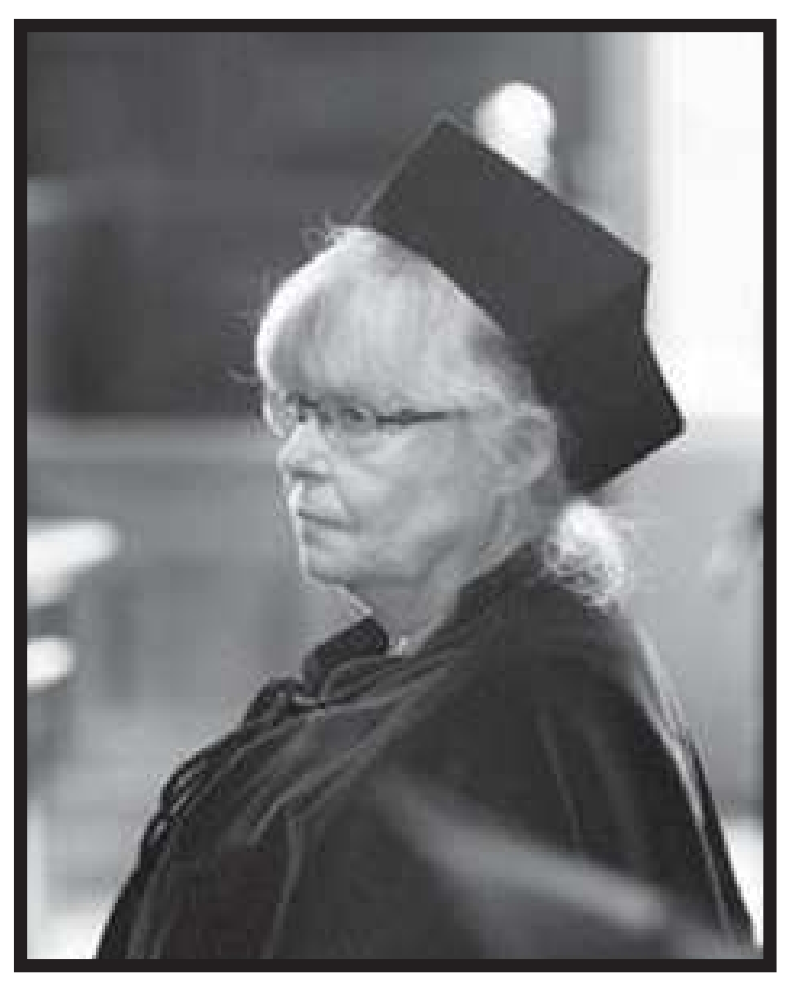
po studiach została skierowana do Biura

Turystyki Młodzieżowej „Juventur”. Do jej zawodowych obowiązków należało m.in. pilotowanie przyjeżdżających do Polski grup z Republiki Federalnej Niemiec i Berlina Zachodniego. Grupy te przygotowywały na terenach byłych obozów koncentracyjnych Auschwitz-Birkenau, Stutthof i Majdanek projekty i wystawy dotyczące zbrodni nazistowskich (Akcja Znaku Pokuty - Służba dla Pokoju - Aktion Sühnezeichen - Friedensdienste). Współuczestnictwo w pracach tych grup ukierunkowało zainteresowania Ewy Bojenko-Izdebskiej i zaowocowało rozpoczęciem badań nad historią Niemiec i nazizmem, a także wzbudziło jej zainteresowania aktualną polityką międzynarodową. 
W 1979 r. Ewa Bojenko-Izdebska rozpoczęła studia doktoranckie w Instytucie Nauk Politycznych Uniwersytetu Jagiellońskiego w Krakowie; w 1982 r. podjęła pracę na stanowisku asystenta, a następnie adiunkta w Katedrze Stosunków Międzynarodowych Instytutu Nauk Politycznych. W instytucie tym pracowała przez 35 lat.

W pierwszej fazie badań zainteresowania naukowe Profesor Ewy Bojenko-Izdebskiej koncentrowały się głównie na działalności Młodych Socjalistów (Junge Sozialisten) organizacji młodzieżowej SPD. Zagadnienie to zdecydowała się też uczynić tematem przyszłej pracy doktorskiej. Badania nad działalnością programową, koncepcjami doktrynalnymi oraz praktyczną polityką tej organizacji prowadziła również w czasie stypendium naukowego, przyznanego jej przez Fundację im. Friedricha Eberta w 1981 r. Efektem tychże badań była obroniona w 1992 r. praca doktorska pt. Koncepcje doktrynalne Mtodych Socjalistów w SPD w latach 1969-1981. Rok później za tę rozprawę dziekan Wydziału Prawa i Administracji Uniwersytetu Jagiellońskiego przyznał Jej nagrodę indywidualną pierwszego stopnia.

Po uzyskaniu stopnia naukowego doktora zainteresowania badawcze Ewy Bojenko-Izdebskiej uległy znaczącemu rozszerzeniu i koncentrowały się na niemieckim systemie partyjnym i politycznym, społecznej gospodarce rynkowej, polityce zagranicznej i bezpieczeństwa RFN, zagadnieniach niemieckiego federalizmu oraz transformacji ustrojowej w Niemczech Wschodnich. W 1991 r. otrzymała stypendium NATO Democratic Institutions Fellowship, które umożliwiło Jej podjęcie badań nad procesem wprowadzania systemu federalnego w NRD po zjednoczeniu Niemiec. W tym samym roku została członkiem Gesellschaft für Deutschlandforschung - organizacji zajmującej się kompleksowymi badaniami nad procesem transformacji w byłej NRD. Wydarzenia te zadecydowały o wyborze tematu przyszłej pracy habilitacyjnej, którym była właśnie transformacja polityczna w Niemczech Wschodnich.

W wyniku przeprowadzenia kompleksowych studiów nad tym zagadnieniem Ewa Bojenko-Izdebska napisała monografię pt. Przemiany w Niemczech Wschodnich 1989-2010. Polityczne aspekty transformacji. Ukazała się ona w $2011 \mathrm{r}$. i była podstawą do wszczęcia postępowania habilitacyjnego. W oparciu o cały dorobek naukowy i rozprawę habilitacyjną Rada Wydziału Studiów Międzynarodowych i Politycznych Uniwersytetu Jagiellońskiego nadała Ewie Bojenko-Izdebskiej w dniu 28 czerwca 2012 r. stopień doktora habilitowanego nauk humanistycznych w zakresie nauk o polityce.

Rozprawa habilitacyjna Ewy Bojenko-Idebskiej była pierwszą w Polsce i Niemczech analizą przemian na poziomie wszystkich tzw. nowych krajów związkowych, czyli terytorium dawnej NRD i Berlina Wschodniego. W książce tej Autorka dokonała rekonstrukcji przemian ustrojowych w Niemczech Wschodnich po 1990 r., badając specyficzny przypadek transformacji przez zjednoczenie, jego konsekwencje dla ustroju zjednoczonych Niemiec, a także dynamikę zmian w poszczególnych krajach związkowych. Autorka wykazała w swej monografii, w jak specyficzny sposób przebiegały procesy transformacji politycznej i gospodarczej w Niemczech Wschodnich. Dokonała skrupulatnej i niezwykle rzetelnej analizy wszystkich istotnych uwarunkowań wewnętrznych i międzynarodowych, czyli strategii zjednoczeniowej rządu RFN, wielomiliardowej pomocy finansowej Niemiec Zachodnich dla nowych krajów związkowych, 
procesu integracji wschodnich landów ze Wspólnotami Europejskimi bez jakichkolwiek warunków przedakcesyjnych oraz wpływu zjednoczenia Niemiec na wzmocnienie pozycji międzynarodowej tegoż państwa. Przyjęte w rozprawie hipotezy badawcze, w szczególności główna hipoteza opierająca się na założeniu, że transformacja w NRD, a potem w Niemczech Wschodnich miała charakter przypadku szczególnego (Sonderfall), zostały w sposób dobitny w tej monografii udowodnione i zweryfikowane na podstawie dostępnych materiałów źródłowych. Autorka przedstawiła w niej również wpływ przemian w dawnej NRD na strukturę systemu politycznego, społecznego i gospodarczego zjednoczonych Niemiec, podważając tym samym rozpowszechnioną zwłaszcza w pierwszym okresie po zjednoczeniu tezę, według której proces zjednoczeniowy nie wpłynął w istotny sposób na zakorzenioną i ustabilizowaną już demokrację zachodnioniemiecką. Autorka wykazała ponadto w swojej rozprawie, że nawet dwie dekady po zjednoczeniu naród i społeczeństwo niemieckie pozostają w dalszym ciągu pod wieloma względami podzielone. $\mathrm{Z}$ tych wszystkich powodów monografia Ewy Bojenko-Izdebskiej wniosła niezwykle istotny wkład w dotychczasowy stan badań niemcoznawczych w Polsce i za granicą.

Profesor Bojenko-Izdebska była autorką łącznie ponad 50 prac naukowych opublikowanych w kraju i za granicą. Uczestniczyła w ponad 40 konferencjach naukowych krajowych i międzynarodowych, zaś jej wystąpienia zawsze dowodziły rozległych horyzontów badawczych. Oprócz przynależności do Gesellschaft für Deutschlandforschung była również członkiem Internationale Vereinigung für Germanistik, Stowarzyszenia Germanistów Polskich, Polskiego Towarzystwa Studiów Międzynarodowych, a także Towarzystwa Polsko-Niemieckiego w Krakowie. Była mocno zaangażowana w rozwój współpracy naukowej z uczelniami w Niemczech, i to do ostatnich chwil. Nagła śmieć spowodowała, że Profesor Ewa Bojenko-Izdebska nie zdążyła już przystąpić do realizacji międzynarodowego projektu z udziałem Uniwersytetu Jagiellońskiego, Uniwersytetu w Lipsku, Uniwersytetu w Pradze oraz Uniwersytetu w Budapeszcie zatytułowanego „Managing multilevel transformation in Europe: An East Central European perspective" - choć przecież była jedną z jego inicjatorek.

W dorobku Pani Profesor na uwagę zasługuje też różnorodna i bogata działalność dydaktyczna. Ewa Bojenko-Izdebska prowadziła związane także z tematyką swoich badań liczne wykłady i ćwiczenia w Instytucie Nauk Politycznych i Stosunków Międzynarodowych na trzech kierunkach studiów: politologii, stosunkach międzynarodowych i bezpieczeństwie narodowym, a także wykłady w Instytucie Historii oraz Instytucie Filologii Germańskiej Uniwersytetu Jagiellońskiego. Dużym zainteresowaniem cieszyły się ponadto Jej seminaria magisterskie i doktoranckie. Studenci i doktoranci cenili zwłaszcza Jej otwartość i serdeczność, szybko niwelujące dystans w relacjach mistrz-uczeń. Ponadto Profesor Ewa Bojenko-Izdebska posiadała znaczący dorobek dydaktyczny w postaci wykładów wygłaszanych w kilku uczelniach Republiki Federalnej Niemiec, np. na Uniwersytecie Friedricha Schillera w Jenie, Uniwersytecie Bundeswehry im. Helmuta Schmidta w Hamburgu i Uniwersytecie w Lipsku, a także wykłady podczas seminariów polsko-niemieckich organizowanych we współpracy z Instytutem Goethego w Krakowie, Międzynarodowym Domem Spotkań Młodzieży w Oświęcimiu 
i Domem Współpracy Polsko-Niemieckiej w Gliwicach. Od początku lat 90. do 2000 r. organizowała z Kołem Stosunków Międzynarodowych Instytutu Nauk Politycznych, a następnie Instytutu Nauk Politycznych i Stosunków Międzynarodowych coroczne międzynarodowe seminaria studenckie w ramach projektu „Europa Środkowa”, których była koordynatorem ze strony polskiej, we współpracy z uniwersytetami z Niemiec, Austrii, Węgier, Słowenii i Czech.

Profesor Ewa Bojenko-Izdebska była również znakomitym tłumaczem przysięgłym języka niemieckiego. Jej dorobek w tym zakresie obejmował tłumaczenia symultaniczne przebiegu konferencji naukowych oraz tłumaczenia wielu tekstów naukowych. Po raz pierwszy przetłumaczyła na język polski napisane w języku niemieckim Listy polskiego szlachcica do niemieckiego publicysty autorstwa Antoniego Helcla. Tekst ten został zamieszczony w zbiorze $O$ prawdziwym i fatszywym konserwatyzmie. Wybór pism ${ }^{1}$.

Za swoją pracę naukową i dydaktyczną Profesor Bojenko-Izdebska była kilkukrotnie nagradzana Nagrodą Rektora Uniwersytetu Jagiellońskiego, a w 2014 r. została odznaczona Złotym Medalem za Długoletnią Służbę.

Pozostała w naszej pamięci nie tylko jako znakomita badaczka problematyki niemcoznawczej, zaangażowany naukowiec i wspaniały nauczyciel akademicki. Zapamiętaliśmy Ją przede wszystkim jako ciepłego, bardzo życzliwego i otwartego na innych człowieka. Z niezwykłą łatwością zaprzyjaźniała się z ludźmi, chętnie pomagała wszystkim, którzy pomocy potrzebowali. Zawsze uśmiechnięta, wiecznie gdzieś się śpiesząca Pani Profesor...

Edyta Chwiej Janusz Józef Węc

A.Z. Helcel, O prawdziwym i fatszywym konserwatyzmie. Wybór pism, Kraków 2007. 